\title{
Sialoceler i glandula parotis
}
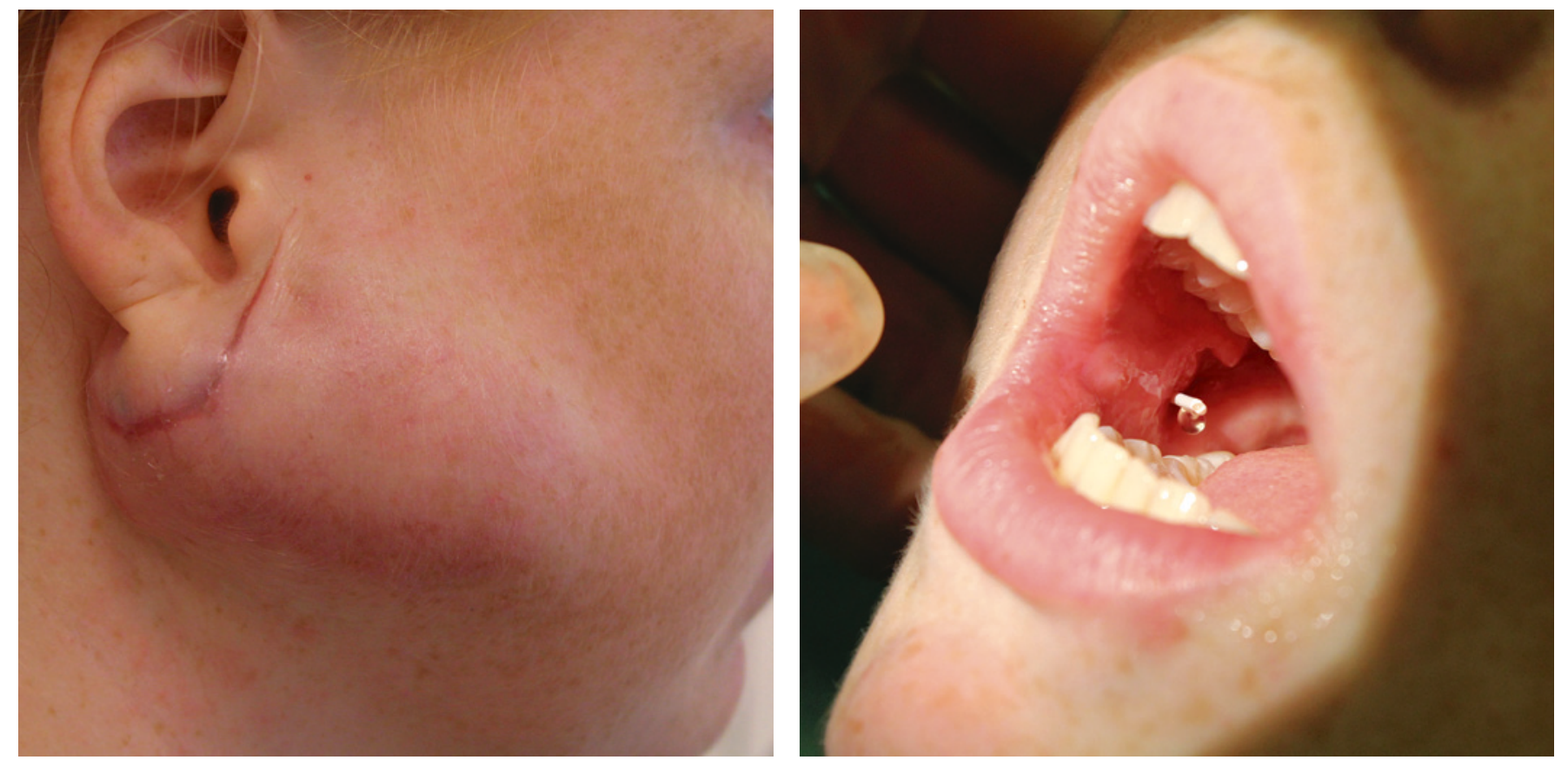

En tidligere frisk kvinne i 20-årene innkom med en stor, fluktuerende hevelse på kinnet snaut to uker etter operasjon for et lite pleomorft adenom i høyre parotiskjertel (bilde 1). Det ble aspirert spyttvæske transkutant, verifisert ved påvisning av amylase, forenlig med et parotissialocele.

Man forsøkte først tradisjonell behandling med repeterte, transkutane punksjoner. I løpet av tre uker tappet man sialocelet for $20-50 \mathrm{ml}$ i alt åtte ganger, men sialocelet residiverte raskt hver gang.

For å minimere risikoen for danning av en transkutan spyttfistel, valgte man i lokalanestesi å punktere sialocelet transoralt med et kateter (Secalon ${ }^{\circledR}$ 18G , 1,4 $\cdot 90 \mathrm{~mm}$ ). Lengden på kateteret ble tilpasset og suturert til kinnslimhinnen, der det sørget for kontinuerlig intraoral drenasje av spyttvæske fra sialocelet (bilde 2). Kateteret ble fjernet etter fire uker, og senere kontroller har vist normal spyttproduksjon og drenasje intraoralt.

Et sialocele er en lokalisert spyttansamling i bløtvevet rundt en spyttkjertel som typisk oppstår 1-2 uker etter skade på utførselsgang eller kjertel, og ses oftest $i$ forbindelse med skarpe traumer og etter parotiskirurgi. Ideelt skal man tilstrebe reparasjon i akuttfasen, men dette er skader som ofte blir oversett. Forsinket eksplorasjon og reparasjon er ikke anbefalt på grunn av risiko for skade av $\mathrm{n}$. facialis.

Det finnes ingen klar konsensus når det gjelder sekundær behandling av parotissialoceler. Prosedyren med innsetting av intraoralt dren ble beskrevet første gang i 1969 (1). Den kan utføres i lokalanestesi, er billig og kan opprettholde gjenværende kjertelfunksjon. I tillegg synes denne metoden å ha færre bivirkninger og krever færre ressurser enn andre behandlingsalternativer (2).

Pasienten har gitt samtykke til at artikkelen blir publisert.

\section{Stian Halse}

Stian.Egset.Halse@ahus.no

\section{Marianne Røkke}

Gregor Bachmann-Harildstad

$\emptyset$ re-nese-halsavdelingen

Akershus universitetssykehus

Stian Halse (f. 1977) er lege i spesialisering.

Forfatter har fylt ut ICMJE-skjemaet og oppgir

ingen interessekonflikter.
Marianne Røkke (f. 1966) er overlege. Forfatter har fylt ut ICMJE-skjemaet og oppgir ingen interessekonflikter.

Gregor Bachmann-Harildstad (f. 1965) er overlege og i tillegg førsteamanuensis og ph.d. ved Universitetet i Oslo.

Forfatter har fylt ut ICMJE-skjemaet og oppgir ingen interessekonflikter.

\section{Litteratur}

1. Meyer RA, Gordon RC. Method for repair of traumatic pseudocyst of parotid duct: report of case. J Oral Surg 1969; 27: 281-3.

2. Donoso T, Domancic S, Argandoña J. Delayed treatment of parotid sialocele: a functional approach and review. J Oral Maxillofac Surg 2015; 73: 284-90.

Mottatt 10.6. 2016, første revisjon innsendt 14.9. 2016, godkjent 26.9. 2016. Redaktør: Ketil Slagstad. 